Article

\title{
The Effects of Divergence between Cash Flow and Voting Rights on the Relevance of Fair Disclosure and Credit Ratings
}

\author{
Jin-Ha Park ${ }^{1, * \mathbb{D}}$, Jiyeon Lee ${ }^{2}$ and Youn-Sik Choi ${ }^{2}$ \\ 1 Department of Accounting, Soongsil University, Seoul 06978, Korea \\ 2 School of Management, Kyung Hee University, Seoul 02447, Korea \\ * Correspondence: parkjh04@ssu.ac.kr; Tel.: +82-2-820-0582
}

Received: 18 May 2019; Accepted: 25 June 2019; Published: 3 July 2019

check for updates

\begin{abstract}
This study investigates the effects of governance structure on the relationship between disclosure quality and credit ratings. Firms with greater control-ownership divergence are more likely to pursue their private interests because controlling shareholders obtain the benefit of managerial decision in accordance with controlling interest and they bear the related risk only to the shareholding value. The greater divergence decreases the level of disclosure, thereby increasing the information asymmetry and agency problems, and, ultimately may be harmful to the firms' sustainability. We analyze data from the listed Korean companies belonging to a large business group that issued corporate bonds for the period 2003-2015, and find that there is a positive relationship between fair disclosure and credit ratings; however, it is weakened as the control-ownership divergence increases. These results suggest that firms with a high quality of disclosure are assigned better credit ratings. However, if their governance structures are poor, the capital market may penalize the reliability of the released information.
\end{abstract}

Keywords: disclosure; credit ratings; ownership-control wedge; sustainability

\section{Introduction}

Disclosure may play a role in eventually enhancing the sustainability of a firm by building trust among its stakeholders. In particular, firm valuation differs greatly depending on how faithfully the manager discloses information about management activities in the capital market, where information asymmetry is usually inherent between firms and their stakeholders. For example, when Mattel was in a crisis in 2007 due to its toys being covered in lead-paint, Robert Eckert, Chief Executive Officer, immediately apologized and voluntarily recalled millions of toys. Mattel's commitment to solving the problem came through in their sincere explanations of the reasons for the recall. Through this, Mattel rebuilt its damaged reputation and regained the trust of its stakeholders. On the contrary, the Doosan Group's stock prices plunged in August 2008, when it announced its plans to issue new stocks for Bobcat, a US construction equipment company that was acquired by Doosan Infracore, without communication with its stakeholders. Doosan was suspected of deliberately delaying the disclosure and the reliability of the company was damaged. In such cases, it is expected that firms with higher disclosure quality will gain more trust in the capital market.

Credit ratings are evaluations of credit risk that predict the ability to repay debt and implicitly forecast the likelihood of default risk. Rating agencies assign credit ratings by assessing firms' ability to generate certain cash flow at certain times in the future. Credit ratings are an important factor in determining risk premiums, that is, capital costs. Thus, it is likely to be affected by how faithfully the management provides information to rating agencies on the firm's ability to repay its principal. 
Sengupta [1] argued that firms providing timely and informative disclosures on their risk are less likely to hide bad information, resulting in lower risk premiums. Subsequent studies found that the higher the disclosure quality, the higher the credit ratings and lower the risk premium [2-8].

However, the relationship between the disclosure quality and credit ratings are influenced by the divergence between cash flow rights (ownership) and voting rights (control), or simply, the control-ownership wedge. This is because the disclosure quality is closely related to corporate governance, rather than being determined independently [9]. This divergence arises when controlling shareholders' voting rights are greater than cash flow rights due to pyramid-type governance structures or cross-shareholding ties among affiliates. In general, the greater the control-ownership divergence, the worse the corporate governance. The greater divergence is associated with more earnings management [10-15], a lower degree of conservatism [16], larger forecast errors [17], and lower credit ratings [18]. In terms of disclosure, smaller quantities of information are disclosed [19], and there is a greater possibility of errors in earnings forecasts [20].

In summary, firms with a greater divergence have incentives to pursue the private interests of controlling shareholders or hiding problems in the corporate governance structure. In this case, there is a possibility that information asymmetry among stakeholders in the capital market will be strengthened, which will result in a negative evaluation of the company. Hence, this study examines the following two hypotheses using credit ratings, which involve the evaluation of the capital market in terms of the usefulness of the disclosed information. First, we empirically analyze that the higher the disclosure level of the company, the higher the credit ratings. Second, we examine how this relationship between disclosure and credit ratings is negatively affected by the divergence between cash flow right and voting right.

The sample used in this study includes firms belonging to a large business group, which issued corporate bonds among the companies listed in KOSPI from 2003 to 2015. We obtained the number of disclosures from the Korea Investor's Network for Disclosure System (KIND), provided by the Korea Exchange. We extracted financial data and credit rating information from the FnGuide, one of the largest providers of financial information on Korean firms. First, we found that there is a significant positive relationship between the level of information disclosed through fair disclosure and credit ratings. Second, this positive relationship is weakened in the case of firms with greater control-ownership divergence, as compared to firms with lesser divergence. These results imply that disclosure quality is considered in the capital market with every aspect of quality and quantity.

This study is expected to contribute in the following ways. First, while extant research provides insights into the relationship among the divergence, disclosure quality, and credit ratings, there is no evidence on how the divergence influences the relevance of fair disclosure and credit ratings. This study fills this void by providing evidence on the mediating role of governance in the disclosure impact on credit ratings. Second, this study suggests that firms should consider their corporate governance at a greater depth when deciding on a disclosure policy. If rating agencies consider the information disclosed by firms with greater control-ownership divergence to be less useful, this will eventually lead to a higher risk premium. Therefore, it is necessary to determine the disclosure policy, keeping in view that the cost of debt can increase if a firm with greater divergence reduces the quality of disclosure for the purpose of hiding the problems associated with its corporate governance. Third, our findings using Korean capital market data, which are consistent with the results of previous research in several ways, can provide generalizable implication that rating agencies take into consideration not only the earnings quality or timeliness of earnings, but also governance structure, such as CEO power or board structure, when assigning credit ratings $[2,21,22]$

The remainder of the paper is organized as follows. Section 2 presents a review of the previous literature and develops the research hypotheses. Section 3 introduces the empirical model and measures used in the analyses. Section 4 reports the results, and Section 5 concludes the study. 


\section{Prior Literature and Hypotheses Development}

\subsection{The Determinants of Credit Ratings}

Previous studies related to corporate credit ratings report that various corporate characteristics such as profitability, corporate governance, the level of earnings management, quality of accounting information, quality of earnings and cash flow, and disclosure quality affect corporate credit ratings [1,2,23-25]. Bhojraj and Sengupta [21] analyzed the relationship between corporate governance and credit ratings. They found that the higher the ratio of institutional investors and outside directors, the lower the bond yield and the higher the credit ratings when issuing corporate bonds. This implies that good corporate governance can weaken the firm's default risk by reducing information risk and the agency problem. In the same vein, Ashbaugh-Skaife et al. [2] examined the impact of corporate governance details on firms' credit ratings using the Standard \& Poor's governance measurement methodology. They showed that the higher the percentage held by the blockholder or the greater the CEO power, the lower the credit ratings. On the other hand, they suggested that the higher the board's independence, board stock ownership, and takeover defences, the higher the company's credit ratings.

In Korea, numerous studies have reported consistent results. They use the quality of accruals and earnings smoothing as proxies for the quality of earnings and found that firms with a higher earnings quality receive better credit ratings as compared to firms with lower earnings quality [24,26,27]. Shin et al. [25] used the corporate governance score (protection of shareholder rights, board characteristics, disclosure, audit committee, and managerial errors) provided by the Korea Corporate Governance Service (KCGS), and reported that the better the corporate governance score, the higher the corporate credit ratings.

\subsection{Disclosure Quality and Credit Ratings}

Prior studies mainly focus on the effects of disclosure on the information environment and cost of capital. The consensus appears to be that a negative relationship between the quality of disclosure and the cost of capital. For example, Botosan [28], Sengupta [1], and Yu [29] found that there is a negative relationship between disclosure and cost of capital. Similarly, using the data of 35 countries, Francis et al. [30] showed that firms benefit from greater disclosure by having a lower cost of capital. More informative and timely disclosure increases investors' awareness of the firm's financial condition, which results in reduced information asymmetry between managers and investors. Since greater disclosure decreases a firm's uncertainty and credit risk, investors are able to reduce the monitoring cost for financial condition, which facilitates a firm's access to lower cost of debt financing.

Financial analysts may affect a firm's default risk through their role as monitors and information intermediaries [31]. By monitoring managerial actions, analysts reduce agency costs related to the separation of ownership and control [32]. Since analysts are significant information intermediaries between managers and market participants, they can reduce uncertainty and information asymmetry in the market by improving the information quality, thereby decreasing default risk [33]. As a result, they contribute to the information environment of the firm. Better reporting quality is associated with less uncertainty about credit risk [34]. Therefore, disclosure quality leads to a lower cost of capital.

The contents of disclosure which includes reporting on intellectual capital, corporate governance, or social issues may affect the default risk. For instance, Orens, Aerts and Lybaert (2009) [35] found that disclosure including intellectual capital reduces the level of information asymmetry and lowers the cost of capital, which, in turn, increases the firm value. La Rosa et al. (2018) [36] showed that corporate social performance has a positive role in reducing the cost of debt capital. In addition, prior studies show that firms with better corporate governance are negatively related to cost of capital [2,21].

In Korea, prior studies generally report the positive effects of disclosure levels and quality. The higher the level of disclosure, the more the effective release of information to the market, resulting in a decrease in changes in stock price due to the release of earnings [37]. The volatility of abnormal returns and trading volumes are reduced at the time of the announcement of earnings [38]. In the case 
of firms with a higher level of disclosure, the analysts' forecast error can be lower, which leads to an improvement in the information environment for investors in the market [39-41]. Yoo et al. [42] showed that managers reduce their costs of capital through the disclosure of earnings forecasts, and found that firms with greater analyst coverage are more likely to reduce their costs of capital. Hwang and Kim [7] reported that even after controlling other influencing factors, the quality of voluntary disclosure lowers the cost of debt. Na and Leem [43] found that the cost of equity is decreased when firms release more information through a fair disclosure system. Lee et al. [44] found that unfaithful disclosure firms on the Korea Exchange are expected to have a low disclosure quality, resulting in a high cost of debt. These results suggest that the management earnings forecast mitigates information asymmetry and reduces information risk, and there is a complementary relationship between management earnings forecasts and information provided by analysts. Yang et al. [4] measured the disclosure quality as foreign investors' holdings, analyst following, number of shareholders, audit quality, and the market, and showed that firms with more expansive disclosure have a lower cost of debt. In sum, results of Korean research suggest that high levels of disclosure have an effect of decreasing the cost of capital by attracting investors, lowering forecast risk, and reducing information asymmetry, which is consistent with previous research.

Credit rating is the measure of the probability that a company will default on its debt. It is used as a basis for determining the level of firms' cost of debt in the capital market. Profitable firms may have a high credit rating because they offer stronger guarantees to debt holders that the interest and principal of their debts will be paid $[25,45,46]$. However, credit rating agencies evaluate managerial risk, industrial risk, business risk, and financial risk in addition to firms' profitability when determining their credit ratings.

Based on the results of previous studies, the disclosure level may have an effect on the firm's future cash-flow forecasts and default risk. If the information is released in a timely manner, investors can easily predict the firm's expected future cash-flow and are unlikely to evaluate the default risk as high. In other words, firms with a more expansive disclosure may reduce risk factors related to information asymmetry between managers and market participants. Investors are more likely to accurately predict the future cash flow and the likelihood of adverse selection is lower. Jung and Lee [8] found that firms with more frequent voluntary disclosures have a larger analyst following and receive higher credit ratings. Jeong et al. [6] showed that inaccurate disclosure information may lower credit ratings. Therefore, we revisit the fact that timely information disclosure affects firms' credit ratings by reducing information asymmetry. This discussion leads to the following hypothesis:

Hypothesis 1 (H1). There is a positive association between disclosure quality and credit ratings.

\subsection{Disclosure Quality and Credit Ratings in Terms of Divergence between Cash-Flow and Voting Rights}

Korean corporate governance practices are characterized by the dominance of large business conglomerates known as Chaebol. These conglomerates normally have a pyramid-type governance structure and cross-shareholdings, which enable controlling shareholders to control all companies belonging to the conglomerate, even with only a small percentage of direct ownership [17]. Under this governance structure, the percentage of cash-flow rights (ownership) is relatively low, while voting rights (control) are comparatively high. This difference is called the divergence between ownership and control, and can significantly influence firms' and managers' behaviour. As the divergence increases, the controlling shareholder gains as much as the controlling interest and bears as much risk as that of the shareholder value. Therefore, in order to pursue their private interests, it is likely that the controlling shareholders infringe upon the rights of minority shareholders, and transfer firms' wealth to themselves via hidden or intra-company transactions [14,47]. Since these behaviours deteriorate the reliability of accounting information, they can have a negative impact on the firm's performance and financial condition, and will reduce its ability of principal repayment [48]. If the level of legal protection for minority shareholders is insufficient, the adverse effect of corporate governance may 
be intensified [49]. In addition, if the controlling shareholders maintain a strong control in these governance structures, various monitoring mechanisms such as the board of directors, the audit committee, or the internal control system may not function well [14,50].

Prior studies show that there is a positive relationship between the control-ownership divergence and firms' earnings management $[11,15,16,20]$. They argue that as the divergence is increased, firms have more incentives to manipulate earnings to build their personal empire or entrenchments. With a divergence between cash-flow and voting rights, the level of accounting conservatism is reduced [16]. Kim [15] found that this divergence affects not only accounting conservatism, but also earnings management, earnings response coefficient, and cost of capital. That is, the greater the divergence between ownership and control, the greater the controlling shareholders' incentive to manipulate earnings, consequently resulting in a reduction in the reliability of accounting information [30].

Controlling shareholders who manipulate earnings have incentives to disclose less information to the market to avoid being detected by the minority shareholders or stakeholders, which results in an increased information asymmetry $[19,51]$. Thus, greater divergence may have a negative effect on information transparency, thereby increasing adverse selection costs and agency risks for market participants. Since less information is available for analysts to predict future earnings, analysts' forecast error increases [17,52]. Hong et al. (2017) [53] found that opaque firms with a large divergence are more crash prone than opaque firms with a small divergence. Rating agencies incorporate corporate governance into the evaluation factor when assigning credit ratings. They also evaluate firms' ownership structure, shareholder rights, financial transparency, and board structure in a comprehensive manner. Thus, firms with a weak ownership structure may have lower credit ratings because information asymmetry and agency problems negatively affect the financial condition [18].

In summary, a greater control-ownership divergence increases the earnings management or decrease level of disclosure, consequently, hindering corporate transparency. The greater the ownership divergence, the more the likelihood of firms providing inaccurate information to the market, resulting in a higher forecast error. In this context, there is a possibility that firms with weak corporate governance try to make disclosures in a way to cosmeticize their ability to repay back the debt. Therefore, we examine the effect of the control-ownership divergence on the relation between fair disclosure level and credit ratings. The second hypothesis is as follows:

Hypothesis 2 (H2). The control-ownership divergence negatively affects the positive relationship between disclosure quality and credit ratings.

\section{Research Methodology}

\subsection{Research Design}

To examine the relationship between disclosure quality and credit ratings, we first estimate the following regression model:

$$
\begin{gathered}
\text { RATING }_{\mathrm{it}}=\beta_{0}+\beta_{1} F D_{\mathrm{it}}+\beta_{2} \text { SIZE }_{\mathrm{it}}+\beta_{3} R O A_{\mathrm{it}}+\beta_{4} L E V_{\mathrm{it}}+\beta_{5} M T B_{\mathrm{it}}+\beta_{6} P P E_{\mathrm{it}}+ \\
\beta_{7} Z_{-} S C O R E_{\mathrm{it}}+\beta_{8} I_{\text {INTEREST }}+\beta_{\mathrm{it}}+\beta_{9} B E T A_{\mathrm{it}}+\beta_{10} F_{\text {FOREIGN }}+Y E A R+I N D U S T R Y+\varepsilon_{\mathrm{it}}
\end{gathered}
$$

where, for firm $\mathrm{i}$ and year $\mathrm{t}, R A T I N G_{\text {it }}$ is the credit rating of corporate bonds assigned by three top rating agencies; $F D_{i t}$ is the number of fair disclosures; $S I Z E_{i t}$ is the natural logarithm of total assets; $R O A_{\text {it }}$ is the net income before the extraordinary items are divided by lagged total assets; $L E V_{\text {it }}$ is the total debt divided by total assets; $M T B_{\text {it }}$ is the market value of the equity divided by the book value of equity; $P P E_{\mathrm{it}}$ is tangible assets divided by the total assets; $Z_{-} S C O R E_{\mathrm{it}}$ is the modified Altman's Z-score of MacKie-Mason(1990) [7,54]; INTEREST $T_{\mathrm{it}}$ is the earnings before interests, taxes, depreciation, and amortization divided by interest expenses; $B E T A_{\mathrm{it}}$ is the firm's beta estimated using a market model over the fiscal year; FOREIGN $\mathrm{it}_{\mathrm{it}}$ is the rate of foreign investor ownership; and YEAR and INDUSTRY are dummy variables to control fixed effects by year and industry, respectively. 
Our dependent variable, $R A T I N G_{i t}$, represents the firm's credit rating. In Korea, companies should receive credit ratings from two or more rating agencies when issuing a corporate bond to raise long-term funds. We conducted an empirical analysis by classifying the corporate credit rating data of three top rating agencies (i.e., Korea Ratings, Nice Investors Service, and Korea Investors Service) as RATING1, RATING2, and RATING3, respectively. We set the order of the RATING1 RATING3 variables at random so that a specific rating agency is not exposed while analyzing results. Credit ratings provided by DataGuide5 are classified into AAA, AA+, AA, AA-, A+, A, A-, BBB+, BBB, BBB-, BB+, BB, BB-, $\mathrm{B}+, \mathrm{B}, \mathrm{B}-, \mathrm{CCC}, \mathrm{CC}, \mathrm{C}$, and $\mathrm{D}$, and converted to downward numbers from $\mathrm{AAA}=20$ to $\mathrm{D}=1$ for the study. In other words, higher numbers mean better ratings. Our main independent variable, $F D_{i t}$, is the number of fair disclosures. Fair disclosures are provided through KIND, the electronic disclosure system of Korea Exchange, and consists of six items, as follows: (1) management forecast, (2) actual (preliminary) results announcement, (3) Future business and management plan, (4) Notice of actual (preliminary) announcement, (5) Matters related to timely disclosure, and (6) others (matters related to fair disclosure). In this study, the total number of disclosures of the above six items is defined as $F D_{\text {it }}$. If the coefficient $\beta_{1}$ has a statistically significant positive value, it means that the more disclosures, the better the credit ratings.

We include several control variables that have been used in previous literature $[1,2,8,21,55]$. The accounting-based ratio of debt to asset $(L E V)$, performance $(R O A)$, interest coverage ratio (INTEREST) and Stability (Z_SCORE) are used to proxy for firms' default risk. The higher the $L E V$, the lower the ROA, INTEREST and Z_SCORE values reflect the greater default risk. We also include the beta $(B E T A)$ to control firm-specific risk. As the BETA increases, the probability of the principal repayments is lower. Thus, it is expected to have a negative relationship with credit ratings. Firm size (SIZE), is included as a control variable and Larger firms face lower risk so they are expected to receive better credit ratings. Market to book ratio $(M T B)$ is included to control growth options. Tangible asset intensity $(P P E)$ is included to control for differences in firms' asset structure. Firms with a greater asset intensity show a lower risk to the principal payments and, thus, are expected to have better credit ratings. Finally, we include foreign investor ownership which is expected to have a positive impact on credit ratings through the monitoring role.

To test hypothesis 2, we estimate the following regression model based on the prior literature $[1,2,21]$ :

$$
\begin{aligned}
& \text { RATING }_{\mathrm{it}}=\beta_{0}+\beta_{1} F_{\mathrm{it}}+\beta_{2} \text { WEDGEHIGH } \mathrm{it}_{\mathrm{it}}+\beta_{3} \text { FD }_{\mathrm{it}} \times W E D G E H I G H_{\mathrm{it}}+\beta_{4} \text { SIZE }_{\mathrm{it}}+ \\
& \beta_{5} R O A_{i t}+\beta_{6} L E V_{i t}+\beta_{7} M T B_{i t}+\beta_{8} P P E_{i t}+\beta_{9} Z_{-} S C O R E_{i t}+\beta_{10} I N T E R E S T_{i t}+ \\
& \beta_{11} B_{E T A_{i t}}+\beta_{12} \text { FOREIGN }_{\mathrm{it}}+\text { YEAR FE }+ \text { INDUSTRY FE }+\varepsilon_{\mathrm{it}}
\end{aligned}
$$

where, for firm i and year $\mathrm{t}$, WEDGEHIGH $H_{\text {it }}$ is a dummy variable that takes the value of one if the ownership divergence of the firm belonging to a large business group is more than the median, and zero otherwise. A significantly negative coefficient $\beta_{3}$ indicates that the positive relationship between the number of disclosures and credit ratings set in hypothesis 1 is weakened as the control-ownership divergence increases.

\subsection{Sample Selection}

An empirical analysis was conducted using data for companies belonging to a large business group that issued corporate bonds among companies listed in KOSPI from 2003 to 2015. Sample selection procedure is reported in Table 1.

Data were collected as follows. We obtained financial data and credit rating information from the DataGuide5 provided by FnGuide, one of the largest providers of financial information on Korean firms. Data about firms belonging to a large business group is disclosed by the Korean Fair Trade Commission. We extracted the number of fair disclosures from KIND. Regulation Fair Disclosure [56] was approved by the Securities and Exchange Commission (SEC) in August 2000. The Korea government adopted this regulation into the Korean stock market in November 2002 to protect investors and prevent unfair trading 
in the stock market. It requires the listed companies to disclose any material information immediately to all investors in the capital market, not only to specific groups such as analysts and institutional investors.

Table 1. Sample Selection Procedure and Sample Composition.

\begin{tabular}{llc}
\hline & \multicolumn{1}{c}{ Sample Selection Criteria } & Firm-Years \\
\hline (1) & Initial Sample: firms listed in KOSPI for the sample period from 2003 to 2015 & 9116 \\
(2) & Sample after deleting firms belonging to the financial industry & 8390 \\
$(3)$ & Sample after deleting firms whose fiscal year-end is not December & 7964 \\
(4) & Sample after deleting firm-year observations with a negative value of assets and shareholders' equity & 7886 \\
(5) & Sample after deleting firms not belonging to a large business group & 2003 \\
(6) & Sample after deleting firms not having credit ratings assigned by rating agencies & 1323 \\
(7) & Final sample after deleting firm-year observations with missing data to create variables used in the & 1281 \\
& & \\
\hline
\end{tabular}

Therefore, the sample period for this study starts in 2003. The sample selection process was performed as per the following general criteria. First, companies listed in the KOSPI for the sample period from 2003 to 2015 equalled 9116 firm-year observations. We excluded financial companies from the analysis and included only companies with a fiscal year-end in December to ensure the comparability of accounting standards. Financial companies have different institutional backgrounds and business structures as compared to non-financial companies. Since the performance of normal business activities is regarded as difficult for firms with negative total assets and capital, they were not included in the sample. In addition, among firms belonging to a large business group, we limited our sample to firm-year observations receiving credit ratings from the three top rating agencies (Korea Ratings, Nice Investors Service, and Korea Investors). Finally, we eliminated observations that were missing variables used in our regression model. The final sample consisted of 1281 firm-year observations. Table 1 presents the sample selection procedure.

\section{Results}

\subsection{Descriptive Statistics and Correlation Analysis}

The descriptive statistics are presented in Table 2. The average credit ratings (RATING1, RATING2, and RATING3) of the corporate bond from the three top rating agencies are 15.650, 15.437, and 15.346, respectively. They are between the ' $\mathrm{A}$ ' grade and ' $\mathrm{A}+$ ' grade and indicate that the probability of principal repayments is high, but is vulnerable to economic conditions and environmental deterioration. A more detailed credit rating distribution of the sample firms is presented in Table 3 . The average and median value of WEDGE are 25.714 and 26.371, respectively. To test the effects of WEDGE, we use the variable WEDGEHIGH that takes the value of one if the WEDGE is higher than the median of the sample, or zero otherwise. The minimum value of WEDGE is negative in the descriptive statistics, which is due to one firm (Dongyang) that has shares in mutual ownership. After excluding two firm-year observations of this one firm, the results remain the same.

(1) Variables' definitions are as follows: RATING1, RATING2, and RATING3 are the credit ratings of corporate bonds assigned by the three top rating agencies; WEDGE is the divergence between cash-flow rights and voting rights; WEDGEHIGH is the dummy variable that takes the value of one if the ownership divergence of the firm belonging to a large business group is more than the median, and zero otherwise; FD is the number of fair disclosures; SIZE is the natural logarithm of the total assets; $R O A$ is the net income before the extraordinary items are divided by lagged total assets; $L E V$ is the total debt divided by total assets; MTB is the market value of equity divided by the book value of equity; PPE refers to the tangible assets divided by the total assets; Z_SCORE is the modified Altman's Z-score of MacKie-Mason(1990); INTEREST is earnings before interests, taxes, depreciation and amortization divided by interest expenses; BETA is the firm's beta estimated using a market model over the fiscal year; FOREIGN is the rate of foreign investor ownership. 
(2) The numbers of firm-year observations of RATING1, RATING2, and RATING3 are 1029, 1100, and 1111, respectively.

(3) Descriptive statistics are calculated after winsorization of the top and bottom $1 \%$ of a continuous variable in their distribution.

Table 2. Descriptive Statistics $(\mathrm{N}=1281)$.

\begin{tabular}{cccccccc}
\hline Variable & Mean & Standard Deviation & Min & Lower Quartile & Median & Upper Quartile & Max \\
\hline RATING1 & 15.650 & 2.868 & 1 & 14 & 16 & 18 \\
RATING2 & 15.437 & 2.997 & 1 & 14 & 16 & 17 \\
RATING3 & 15.346 & 2.993 & 1 & 14 & 16 & 20 \\
FD & 6.032 & 5.804 & 0 & 1 & 5 & 17 & 20 \\
WEDGE & 25.714 & 20.109 & -4.39 & 4.592 & 26.371 & 38.902 & 17 \\
WEDGEHIGH & 0.5 & 0.5 & 0 & 0 & 0 & 26.012 \\
SIZE & 21.992 & 1.368 & 19.052 & 21.043 & 22.003 & 22.987 \\
ROA & 0.049 & 0.050 & -0.095 & 0.022 & 0.044 & 0.076 \\
LEV & 0.574 & 0.165 & 0.193 & 0.462 & 0.587 & 0.682 \\
MTB & 1.118 & 0.440 & 0.589 & 0.853 & 0.991 & 1.229 \\
PPE & 0.366 & 0.190 & 0.002 & 0.218 & 0.373 & 0.190 \\
Z_SCORE & 1.770 & 0.748 & 0.330 & 1.270 & 1.641 & 3.1951 \\
INTEREST & 0.175 & 0.607 & 0 & 0.025 & 0.053 & 2.170 \\
BETA & 0.964 & 0.389 & 0.110 & 0.690 & 0.980 & 0.111 \\
FOREIGN & 0.187 & 0.152 & 0 & 0.061 & 0.152 & 1.250 \\
\hline
\end{tabular}

Table 3. The distribution of the sample firms' credit ratings.

\begin{tabular}{cccccc}
\hline \multirow{2}{*}{ Credit Ratings } & $\begin{array}{c}\text { Credit Ratings } \\
\text { Number }\end{array}$ & \multicolumn{3}{c}{ Firm-Year Obs. } & \multirow{2}{*}{ Classification } \\
\cline { 3 - 5 } & 20 & 70 & 70 & 68 & \\
\hline AAA & 19 & 86 & 87 & 84 & \\
AA+ & 18 & 108 & 116 & 108 & Investment \\
AA & 17 & 174 & 167 & 155 & Grade \\
AA- & 16 & 137 & 141 & 144 & \\
A+ & 15 & 145 & 152 & 171 & \\
A & 14 & 115 & 110 & 129 & \\
A- & 13 & 61 & 88 & 88 & \\
\hline BBB+ & 12 & 65 & 97 & 83 & \\
BBB & 11 & 29 & 32 & 30 & Grade \\
BBB- & 10 & 16 & 15 & 21 & \\
BB+ & 9 & 3 & 3 & 8 & \\
BB & 8 & 2 & 2 & 3 & Non-Investment \\
BB- & 7 & 2 & 2 & & \\
B+ & 6 & 1 & & 2 & \\
B & 5 & 1 & 2 & 11 & \\
B- & 4 & 6 & 10 & & \\
CCC & 3 & & & & \\
CC & 2 & 3 & 2 & 3 & \\
C & 1 & 2 & 4 & 3 & \\
D & & 1029 & 1100 & 1111 & \\
\hline Sum & & & & &
\end{tabular}

Table 3 provides the distribution of the firms' credit ratings. While the distribution of credit ratings by the three top rating agencies is similar, most of the observations are assigned the investment grade. In the case of RATING1, firm-year observations in the investment grade are 835, accounting for $81.1 \%$ of the total, while firm-year observations in the non-investment grade are 194, accounting for $18.9 \%$ of the total.

Table 4 presents the Pearson correlation between our main variables. First, there is a significant positive correlation between credit ratings (RATING1, RATING2, and RATING3) at the $1 \%$ level. The number of fair disclosures $(F D)$ and credit ratings are significantly positive at the $1 \%$ level. This is consistent with previous studies, which find that firms with more expansive disclosures have higher credit ratings. On the other hand, a relatively higher control-ownership divergence (WEDGEHIGH) is negatively correlated with the credit ratings and fair disclosure frequency $(F D)$ at the $1 \%$ level. This implies that firms with a greater divergence have lower credit ratings [18] and fewer fair disclosures [19]. 
Table 4. The correlation matrix.

\begin{tabular}{|c|c|c|c|c|c|c|c|c|c|c|c|c|c|c|}
\hline Variable & (1) & (2) & (3) & (4) & (5) & (6) & (7) & (8) & (9) & (10) & (11) & (12) & (13) & (14) \\
\hline (1) RATING1 & 1 & & & & & & & & & & & & & \\
\hline (2) RATING2 & $0.989^{* * *}$ & 1 & & & & & & & & & & & & \\
\hline (3) RATING3 & $0.981^{* * *}$ & $0.986^{* * *}$ & 1 & & & & & & & & & & & \\
\hline (4) $F D$ & $0.355^{* * *}$ & $0.372^{* * *}$ & $0.390 * * *$ & 1 & & & & & & & & & & \\
\hline (5) WEDGEHIGH & $-0.181^{* * *}$ & $-0.182 * * *$ & $-0.217^{* * *}$ & $-0.215^{* * *}$ & 1 & & & & & & & & & \\
\hline (6) SIZE & $0.498^{* * *}$ & $0.491^{* * *}$ & $0.505 * * *$ & $0.477^{* * *}$ & $-0.291 * * *$ & 1 & & & & & & & & \\
\hline (7) $R O A$ & $0.329^{* * *}$ & $0.343^{* * *}$ & $0.292 * * *$ & $0.170^{* * *}$ & $-0.079 * *$ & -0.038 & 1 & & & & & & & \\
\hline (8) $L E V$ & $-0.526^{* * *}$ & $-0.539 * * *$ & $-0.520 * * *$ & -0.034 & $0.060 *$ & $0.066 *$ & $-0.420 * * *$ & 1 & & & & & & \\
\hline (9) $M T B$ & $0.128^{* * *}$ & $0.137 * * *$ & $0.118^{* * *}$ & $0.169^{* * *}$ & $-0.065 *$ & $-0.102 * * *$ & $0.452 * * *$ & $-0.142 * * *$ & 1 & & & & & \\
\hline (10) $P P E$ & 0.058 & $0.072 *$ & $0.079^{* * *}$ & -0.035 & 0.023 & 0.048 & 0.010 & -0.045 & $-0.099 * * *$ & 1 & & & & \\
\hline (11) Z_SCORE & $0.342 * * *$ & $0.362 * * *$ & $0.282 * * *$ & 0.048 & -0.011 & $-0.098 * * *$ & $0.539 * * *$ & $-0.270^{* * *}$ & $0.284^{* * *}$ & $-0.246^{* * *}$ & 1 & & & \\
\hline (12) INTEREST & $0.152 * * *$ & $0.158^{* * *}$ & $0.127^{* * *}$ & $0.059 *$ & -0.001 & 0.009 & $0.216^{* * *}$ & $-0.178^{* * *}$ & $0.180^{* * *}$ & $-0.077^{* *}$ & $0.164^{* * *}$ & 1 & & \\
\hline (13) BETA & $-0.154^{* * *}$ & $-0.158^{* * *}$ & $-0.096^{* *}$ & $0.129^{* * *}$ & $-0.096^{* * *}$ & $0.249^{* * *}$ & $-0.071 *$ & $0.177^{* * *}$ & 0.011 & $-0.126^{* * *}$ & $-0.120 * * *$ & 0.046 & 1 & \\
\hline (14) FOREIGN & $0.532 * * *$ & $0.534 * * *$ & $0.555^{* * *}$ & $0.403^{* * *}$ & $-0.318 * * *$ & $0.486^{* * *}$ & $0.373^{* * *}$ & $-0.328^{* * *}$ & $0.210^{* * *}$ & 0.027 & $0.127^{* * *}$ & $0.184^{* * *}$ & 0.049 & 1 \\
\hline
\end{tabular}




\subsection{Main Regression Analysis}

Table 5 presents the results of Hypothesis 1 and reports the relationship between fair disclosure and credit ratings. The dependent variables of column (1) to (3) are credit ratings, RATING1, RATING2, and RATING3 provided by the three top rating agencies, respectively, and the variable of interest is the frequency of fair disclosure, $F D$. The estimated values of $\beta_{1}$ are 0.033 (z-stat $\left.=4.30\right), 0.034(z$-stat $=4.61)$, and 0.035 (z-stat $=4.66)$, respectively, and are significant at the $1 \%$ level. In this study, since credit ratings are defined as $\mathrm{AAA}=20$ to $\mathrm{D}=1$, the positive coefficient on $F D$ implies that the more informative disclosures that are found, the better the credit ratings. Therefore, the positive coefficients confirm the positive relationship between fair disclosure and credit ratings in firms belonging to a large business group. These results are qualitatively consistent with the findings of prior studies. As expected, the coefficient of control variables such as SIZE, MTB, PPE, Z_SCORE, INTEREST, and FOREIGN have significant positive relationships with credit ratings. On the contrary, the coefficients on $L E V$ and BETA have a significant negative association with credit ratings.

Table 5. The relationship between fair disclosure and credit ratings.

\begin{tabular}{cccc}
\hline \multirow{2}{*}{ Variables } & $\mathbf{( 1 )}$ & $\mathbf{( 2 )}$ & $\mathbf{( 3 )}$ \\
& RATING1 & RATING2 & RATING3 \\
\hline \multirow{2}{*}{ FD } & $0.033^{* * *}$ & $0.034^{* * *}$ & $0.035^{* * *}$ \\
& $(4.30)$ & $(4.61)$ & $(4.66)$ \\
SIZE & $0.741^{* * *}$ & $0.735^{* * *}$ & $0.706^{* * *}$ \\
& $(16.67)$ & $(17.16)$ & $(17.27)$ \\
ROA & $-3.159^{* * *}$ & $-3.214^{* * *}$ & $-3.614^{* * *}$ \\
& $(-3.07)$ & $(-3.24)$ & $(-3.65)$ \\
LEV & $-5.737^{* * *}$ & $-5.785^{* * *}$ & $-5.572^{* * *}$ \\
& $(-19.62)$ & $(-20.49)$ & $(-20.23)$ \\
MTB & $0.465^{* * *}$ & $0.503^{* * *}$ & $0.345^{* * *}$ \\
& $(4.72)$ & $(5.33)$ & $(3.71)$ \\
PPE & $0.752^{* * *}$ & $0.789^{* * *}$ & $0.871^{* * *}$ \\
& $(3.36)$ & $(3.73)$ & $(4.29)$ \\
Z_SCORE & $0.580^{* * *}$ & $0.511^{* * * *}$ & $0.570^{* * *}$ \\
& $(9.34)$ & $(8.21)$ & $(9.95)$ \\
INTEREST & $0.143^{* * *}$ & 0.098 & $0.098^{*}$ \\
& $(2.37)$ & $(1.38)$ & $(1.74)$ \\
BETA & $-0.813^{* * *}$ & $-0.782^{* * *}$ & $-0.688^{* * *}$ \\
& $(-7.56)$ & $(-7.40)$ & $(-6.68)$ \\
FOREIGN & $2.862^{* * *}$ & $2.595^{* * *}$ & $3.102^{* * * *}$ \\
YEAR & $(9.13)$ & $(8.09)$ & $(9.92)$ \\
INDUSTRY & YES & YES & YES \\
N & YES & YES & YES \\
LR Chi2 & 1029 & 1100 & 1111 \\
PSeudo R2 & 1646.58 & 1717.04 & 1731.85 \\
& 0.341 & 0.329 & 0.328 \\
\hline
\end{tabular}

Note: Variables are defined in Table 2. Ordered probit regression is used, and the z-statistics are in parentheses. ${ }^{*} \mathrm{p}<0.1 ;{ }^{* * *} \mathrm{p}<0.01$.

Table 6 presents the results of Hypothesis 2 and reports the impact of control-ownership divergence on the relationship between fair disclosure and credit ratings. The dependent variables of column (1) to (3) are credit ratings, RATING1, RATING2, and RATING3, respectively, and the variables of interest are $F D^{*} W E D G E H I G H$, the interaction terms of fair disclosure and the divergence. The coefficients of $F D$ are positive and significant at the $1 \%$ level, consistent with Hypothesis 1 (Table 6, columns 1, 2, 3). The coefficients on the interaction term, $F D^{*} W E D G E H I G H$, are negative and significant at the $5 \%$ level; specifically, the estimated values are -0.026 (z-stat $=-2.01$ ) using RATING1 as a dependent variable and -0.031 ( $\mathrm{z}$-stat $=-2.55$ ) using RATING3. These results confirm our second hypothesis that the high divergence (weak corporate governance) weakens the positive effect of fair disclosure on credit ratings. 
The coefficients of WEDGEHIGH are positive and significant at the $1 \%$ level, suggesting that the higher the control-ownership divergence, the better the firm's credit ratings. This can be explained in terms of the demand for disclosure in the capital market. The demand for disclosure arises from information asymmetry and interest conflicts between managers and investors [56]. Firms with a weak governance structure are likely to receive lower credit ratings because the associated information asymmetry and agency problems negatively affect their financial condition. In this circumstance, managers may have fundamental incentives to provide more informative and credible disclosure to reduce information asymmetry. That is, fair disclosure can mitigate the negative impact of the divergence on credit ratings, therefore, rating agencies evaluate the effort of greater disclosure appropriately, even if the divergence is high.

Table 6. The effects of the control-ownership divergence on the relationship between disclosure and credit ratings.

\begin{tabular}{|c|c|c|c|}
\hline Variables & $\begin{array}{c}\text { (1) } \\
\text { RATING1 }\end{array}$ & $\begin{array}{c}(2) \\
\text { RATING2 }\end{array}$ & $\begin{array}{c}\text { (3) } \\
\text { RATING3 }\end{array}$ \\
\hline$F D$ & $\begin{array}{c}0.046^{* * *} \\
(4.80)\end{array}$ & $\begin{array}{c}0.042 * * * \\
(4.69)\end{array}$ & $\begin{array}{c}0.050 * * * \\
(5.33)\end{array}$ \\
\hline WEDGEHIGH & $\begin{array}{c}0.298^{* * *} \\
(2.82)\end{array}$ & $\begin{array}{c}0.243^{* * *} \\
(2.42)\end{array}$ & $\begin{array}{c}0.313^{* * *} \\
(3.16)\end{array}$ \\
\hline FD*WEDGEHIGH & $\begin{array}{c}-0.026^{* *} \\
(-2.01)\end{array}$ & $\begin{array}{l}-0.019 \\
(-1.49)\end{array}$ & $\begin{array}{c}-0.031 \text { ** } \\
(-2.55)\end{array}$ \\
\hline SIZE & $\begin{array}{c}0.746^{* * *} \\
(16.75)\end{array}$ & $\begin{array}{c}0.747^{* * *} \\
(17.30)\end{array}$ & $\begin{array}{c}0.720^{* * *} \\
(17.46)\end{array}$ \\
\hline$R O A$ & $\begin{array}{c}-3.065^{* * *} \\
(-2.97)\end{array}$ & $\begin{array}{c}-3.100 * * * \\
(-3.09)\end{array}$ & $\begin{array}{c}-3.472 * * * \\
(-3.49)\end{array}$ \\
\hline$L E V$ & $\begin{array}{c}-5.769^{* * *} \\
(-19.68)\end{array}$ & $\begin{array}{c}-5.807^{* * *} \\
(-20.49)\end{array}$ & $\begin{array}{c}-5.600 * * * \\
(-20.26)\end{array}$ \\
\hline MTB & $\begin{array}{c}0.477^{* * *} \\
(4.82)\end{array}$ & $\begin{array}{c}0.530^{* * *} \\
(5.58)\end{array}$ & $\begin{array}{c}0.380^{* * * *} \\
(4.06)\end{array}$ \\
\hline$P P E$ & $\begin{array}{c}0.759 * * * \\
(3.39)\end{array}$ & $\begin{array}{c}0.752 * * * \\
(3.54)\end{array}$ & $\begin{array}{c}0.854^{* * *} \\
(4.20)\end{array}$ \\
\hline Z_SCORE & $\begin{array}{c}0.583 * * * \\
(9.38)\end{array}$ & $\begin{array}{c}0.500 * * * \\
(8.01)\end{array}$ & $\begin{array}{c}0.574^{* * *} \\
(10.02)\end{array}$ \\
\hline INTEREST & $\begin{array}{c}0.126^{* *} \\
(2.09)\end{array}$ & $\begin{array}{c}0.091 \\
(1.26)\end{array}$ & $\begin{array}{l}0.081 \\
(1.43)\end{array}$ \\
\hline BETA & $\begin{array}{c}-0.813^{* * *} \\
(-7.54)\end{array}$ & $\begin{array}{l}-0.785 \\
(-7.42)\end{array}$ & $\begin{array}{c}-0.695^{* * * *} \\
(-6.74)\end{array}$ \\
\hline FOREIGN & $\begin{array}{c}2.910^{* * *} \\
(9.11)\end{array}$ & $\begin{array}{c}2.654^{* * *} \\
(8.10)\end{array}$ & $\begin{array}{c}3.105^{* * *} \\
(9.77)\end{array}$ \\
\hline YEAR FE & Yes & Yes & Yes \\
\hline INDUSTRY FE & Yes & Yes & Yes \\
\hline$N$ & 1029 & 1100 & 1111 \\
\hline LR Chi2 & 1654.55 & 1722.98 & 1742.06 \\
\hline Pseudo R2 & 0.343 & 0.331 & 0.330 \\
\hline
\end{tabular}

Variables are defined in Table 2. Ordered probit regression is used, and the z-statistics are in parentheses. ${ }^{* *} \mathrm{p}<0.05$; *** $\mathrm{p}<0.01$

\section{Discussion and Conclusions}

This study investigated the effects of corporate ownership structure on the relationship between disclosure quality and credit ratings. We measured disclosure quality as the frequency of fair disclosure and governance structure as the divergence between cash-flow rights and voting rights. Using the data for the listed Korean companies belonging to a large business group from 2003 to 2015, we find that there is a positive relationship between disclosure quality and credit ratings, However, this positive impact is reduced as the control-ownership divergence increases. These results suggest that the capital 
market is aware of the disclosure quality considering both the quantitative and qualitative aspects of the information disclosed.

While existing studies provide insights into the relationship among the divergence, disclosure and ratings, there is no evidence on how the control-ownership divergence affect the relationship between fair disclosure and credit ratings. Our study may fill this void. Disclosure is a way of communication between the firm and its stakeholders and plays a significant role in mitigating the information asymmetry in the capital market. Managers need to determine the disclosure policy in a comprehensive manner, considering how firm characteristics such as governance structure and disclosed information is recognized and evaluated in the market. By providing informative and timely information to stakeholders of the capital market, firms can build better trust and a positive reputation. Good trust and reputation will not only bring short-term benefits of reducing the cost of capital but also ultimately enhance the firms' sustainability in the long term. In this sense, this study is expected to provide important policy implications for academics and in practice.

This study has a limitation of the proxy for fair disclosure. Based on the prior literature, we use the frequency of fair disclosure as a proxy for the level of disclosure. However, this may not properly reflect managers' incentive or their disclosure behaviours.

Author Contributions: All three authors together conceptualized the idea. J.-H.P. and J.L. conducted formal analysis under supervision of Y.-S.C. Y.-S.C., J.-H.P., and J.L wrore, reviewed, and edited the paper.

Funding: This research received no external funding.

Acknowledgments: We appreciate helpful comments and constructive suggestions from anonymous reviewers.

Conflicts of Interest: The authors declare no conflict of interest.

\section{References}

1. Sengupta, P. Corporate disclosure quality and the cost of debt. Account. Rev. 1998, 73, 459-474.

2. Ashbaugh-Skaife, H.; Collins, D.W.; LaFond, R. The effects of corporate governance on firms' credit ratings. J. Account. Econ. 2006, 42, 203-243. [CrossRef]

3. Lee, A.Y.; Kim, S.H.; Kang, Y.S. The firms in large business group and the voluntary disclosure. Korean J. Account. Res. 2012, 17, 57-81. (In Korean)

4. Yang, D.H.; Lee, S.C.; Yoon, J.C. Effects of disclosure quality on cost of debt. Korean Manag. Rev. 2011, 40, 803-830. (In Korean)

5. Lee, S.C. A study on the relationship between disclosure quality and cost of debt capital. Korean Account. J. 2011, 20, 1-34. (In Korean)

6. Jeong, K.H.; Lee, D.; Jeong, S.W. The type of preliminary earnings announcement and commercial paper credit rating. Korean Manag. Rev. 2013, 42, 383-410. (In Korean)

7. Hwang, K.; Kim, K. The effect of voluntary disclosure quality on the cost of debt. Korean Account. J. 2013, 22, 369-397. (In Korean)

8. Jeong, M.; Lee, S.C. Effects of timely disclosure level on the number of financial analysts and bond ratings. Korean Account. J. 2015, 24, 1-36.

9. Eng, L.L.; Mak, Y.T. Corporate governance and voluntary disclosure. J. Account. Public Policy. 2003, 22, 325-345. [CrossRef]

10. Claessens, S.; Djankov, S.; Lang, L.H.P. The separation of owership and control in East Asian Corporations. J. Financ. Econ. 2000, 58, 81-112. [CrossRef]

11. Kim, J.B.; Yi, C.H. Ownership structure, business group affiliation, listing status, and earnings management: evidence from Korea. Contemp. Account. Res. 2006, 23, 427-464. [CrossRef]

12. Ahn, H.B. The empirical study on relationship of firm's governance-owener structure and earnings management. Korean Account. Rev. 2004, 29, 117-154. (In Korean)

13. Mork, R.; Shleifer, A.; Vishny, R. Management ownership and market valuation. J. Financ. Econ. 1998, 20, 293-315. [CrossRef]

14. Shleifer, A.; Vishny, R. A survey of corporate governance. J. Financ. 1997, 52, 737-783. [CrossRef]

15. Kim, K.T. The level of wedge and accounting transparency. Account. Audit. Res. 2008, 48, 73-108. (In Korean) 
16. Kim, M.I.; Choi, J.H. The association between the wedge between voting right and cash flow right and conservatism. Account. Audit. Res. 2008, 47, 181-210. (In Korean)

17. Sonu, C.H.; Choi, J.H.; Lee, B.H. The effect of the wedge between voting right and cash flow right on error in analysis' earnings forecasts. Korean Account. Rev. 2010, 35, 1-34.

18. Yoo, H.Y.; Lee, A.Y.; Chae, S.J. The effect of controlling shareholders' ownership structure on firms' credit rating. J. Ind. Econ. Bus. 2016, 29, 2499-2518. (In Korean)

19. Shim, H.; Lee, M.; Choi, J.H. Ownership divergence and the frequency of information disclosure. Korean Account. Rev. 2010, 35, 39-74.

20. Kim, H.J.; Park, M.K. The impacts of the wedge on the association between earnings management and management forecast errors. J. Account. Financ. 2016, 34, 1-25. (In Korean)

21. Bhojraj, S.; Sengupta, P. Effect of corporate governance on bond ratings and yields: the role of institutional investors and outside directors. J. Bus. 2003, 76, 455-475. [CrossRef]

22. Liu, Y.; Jiraporn, P. The effect of CEO power on bond rating and yields. J. Empir. Financ. 2010, 17, 744-762. [CrossRef]

23. Jorion, P.; Shi, C.; Zhang, S. Tightening credit standards: the role of accounting quality. Rev. Account. Stud. 2009, 14, 123-160. [CrossRef]

24. Park, J.I.; Park, C.W. Does income smoothing improve bond ratings?-some empirical evidence on KOSPI and KOSDAQ listed firms-. Tax Account. J. 2012, 13, 9-47. (In Korean)

25. Shin, J.Y.; Suh, C.W.; Park, J.I. The effect of corporate governance on the association between earnings and credit ratings. Korean Management Review. 2012, 41, 1309-1345. (In Korean)

26. Na, I.C.; Kim, J.H. Does accrual quality moderate the informativeness of earnings with respect to corporate bond ratings? J. Account. Financ. 2009, 27, 241-273.

27. Kim, M.T.; Wee, J.B.; Jeon, S.I. Controlling effects of corporate bond grading system on earnings management. Asia-Pacific J. Financ. Stud. 2006, 35, 45-74. (In Korean)

28. Botosan, C.A. Disclosure level and cost of equity capital. Account. Rev. 1997, 72, 323-349.

29. Yu, F. Accounting transparency and the term structure of credit spreads. J. Financ. Econ. 2005, 75, 53-84. [CrossRef]

30. Francis, J.; Lafond, R.; Olsson, P.; Schipper, K. The market pricing of accruals quality. J. Account. Res. 2005, 39, 295-327. [CrossRef]

31. Cheng, M.; Subramanyam, K.R. Analyst following and credit ratings. Contemp. Account. Res. 2008, 25, 1007-1043. [CrossRef]

32. Jensen, M.C.; Meckling, W.H. Theory of the firm: managerial behavior, agency cost and ownership structure. J. Financ. Econ. 1976, 3, 305-360. [CrossRef]

33. Mansi, S.A.; Maxwell, W.F.; Miller, D.P. Analyst forecast characteristics and the cost of debt. Rev. Account. Stud. 2011, 16, 116-142. [CrossRef]

34. Akins, B. Financial reporting quality and uncertainty about credit risk among rating agencies. Account. Rev. 2018, 93, 1-22. [CrossRef]

35. Orens, R.; Aerts, W.; Lybaert, N. Intellectual capital disclosure, cost of finance and firm value. Manag. Decis. 2009, 47, 1536-1554. [CrossRef]

36. La Rosa, F.; Liberatore, G.; Mazzi, F.; Terzani, S. The impact of corporate social performance on the cost of debt and access to debt financing for listed European non-financial firms. Eur. Manag. J. 2018, 36, 519-529. [CrossRef]

37. Lee, B.H. Essays on the intraday market response to corporate disclosure subject to regulation fair disclosure. Ph.D.Thesis, Seoul National University, Seoul, Korea, 2009.

38. Kim, J.H.; Chang, J.H.; Yeo, E.J. The effect of regulation fair disclosure on market responses to earnings disclosure. Korea Bus. Rev. 2005, 34, 1895-1915. (In Korean)

39. Oh, W.J.; Sohn, S.K. An empirical study on the effect of regulation fair disclosure and firm incentives associated with the decision to provide information through fair disclosure. Korea Bus. Rev. 2006, 35, 1449-1478. (In Korean)

40. Kwon, S.Y.; Lee, D.H.; Hwang, M.H. The accuracy of management earnings forecast after adopting regulation fair disclosure. Korean Account.Rev. 2009, 34, 107-141. (In Korean)

41. Lee, S.Y.; Roh, B.G. The change in earnings value relevance driven by regulation fair disclosure. Korean Account. Rev. 2011, 36, 37-70. (In Korean) 
42. Yoo, G.S.; Cha, S.M.; Yoo, Y.K.; Rhee, C.S. Management earnings forecasts and cost of equity capital: Korean evidence. Korean Account. Rev. 2013, 38, 209-243. (In Korean)

43. Na, Y.; Leem, W.B. An empirical analysis on association between fair disclosure and the cost of equity capital. Korean Account. Rev. 2014, 39, 1-42. (In Korean)

44. Lee, A.Y.; Chun, S.B.; Park, S.S. The effect of unfaithful disclosure on the cost of debt. Korean Account. Rev. 2008, 33, 127-158. (In Korean)

45. Jiang, J. Beating earnings benchmarks and the cost of debt. Account. Rev. 2008, 83, 377-416. [CrossRef]

46. Park, J.I.; Yoon, S.R. Earnings management intervals and means: comparative study of credit rating and cost of debt. Korean Account. Rev. 2013, 38, 209-260.

47. Claessens, S.; Djankov, S.; Fan, J.P.H.; Lang, L.H.P. Disentangling the incentive and entrenchment effects of large shareholdings. J. Financ. 2002, 57, 2741-2771. [CrossRef]

48. Fan, J.P.H.; Wong, T.J. Corporate ownership structure and the informatvieness of accounting earnings in east Asia. J. Account. Econ. 2002, 22, 401-425. [CrossRef]

49. La Porta, R.; de Silanes, L.; Sheleifer, A.; Vishnny, R. Corporate ownership around the world. J. Financ. Econ. 1999, 58, 3-27. [CrossRef]

50. Johnson, S.; Boone, P.; Breach, A.; Friedman, E. Corporate governance in the Asia financial crisis. J. Financ. Econ. 2000, 58, 141-186. [CrossRef]

51. Hope, O.; Thomas, W.B. Managerial empire building and firm disclosure. J. Account. Res. 2008, 46, 591-626. [CrossRef]

52. Land, M.H.; Lundholm, R. Corporate disclosure policy and analyst behavior. Account. Rev. 1996, 71, 467-492.

53. Hong, H.A.; Kim, J.B.; Welker, M. Divergence of cash flow and voting rights, opacity, and stock price crash risk: international evidence. J. Account. Res. 2017, 55, 1167-1212. [CrossRef]

54. MacKie-Mason, J.K. Do taxes affect corporate financing decisions? J. Finan. 1990, 45, 1471-1491. [CrossRef]

55. Kim, M.T.; Kim, Y.H. The impacts of foreign ownership and outside directors on bond grading. Korean Account. Rev. 2007, 32, 29-58. (In Korean)

56. Healy, P.M.; Palepu, K. Information asymmetry, corporate disclosure, and the capital markets: A review of the empirical disclosure literature. J. Account. Econ. 2001, 31, 405-440. [CrossRef]

(C) 2019 by the authors. Licensee MDPI, Basel, Switzerland. This article is an open access article distributed under the terms and conditions of the Creative Commons Attribution (CC BY) license (http://creativecommons.org/licenses/by/4.0/). 